\title{
Rancang Bangun dan Analisis Opening Bumper Program TV dalam bentuk Motion Graphic (Studi Kasus: Bincang Santai di iNews TV Batam)
}

\author{
Evaliata Br Sembiring ${ }^{1}$, Jonathan Elsson Suhendra ${ }^{2}$, Prasetyo Dharsono ${ }^{3}$ \\ Program Studi Teknik Multimedia dan Jaringan, Jurusan Teknik Informatika, Politeknik Negeri Batam ${ }^{1,2}$, \\ INews TV Batam ${ }^{3}$

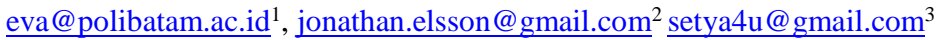

\begin{tabular}{|c|c|}
\hline Article Info & ABSTRACT \\
\hline Article history: & Opening Bumper is a short animation opening video in a program that \\
\hline Received Jun $12^{\text {th }}, 2021$ & $\begin{array}{l}\text { describes the identity of an event or agency. One of the } T V \text { programs was } \\
\text { "Bincang Santai" which airs on the local television station, iNews Batam. }\end{array}$ \\
\hline Revised Aug 20"th, 2021 & However, the opening bumper of the "Bincang Santai" program has been \\
\hline Accepted Aug 26 ${ }^{\text {th }}, 2021$ & $\begin{array}{l}\text { showing for more than } 4 \text { years, which doesn't represent the identity of the } \\
\text { current "Bincang Santai" program. Therefore, a new opening bumper was }\end{array}$ \\
\hline Keyword: & $\begin{array}{l}\text { made in motion graphic form. In making the opening bumper, the Sherwood- } \\
\text { Rout method was used. Furthermore, analysis of the feasibility as an opening }\end{array}$ \\
\hline Opening Bumper & bumper and the perception of the public through the EPIC Model approach. \\
\hline Motion Graphic & The results of the research are: (1) The resulting opening bumper has a \\
\hline TV Program & snippet of the "Bincang Santai" TV program with various motion graphic \\
\hline Sherwood-Rout & $\begin{array}{l}\text { elements; (2) Opening bumper as the "Bincang Santai" opening bumper is } \\
\text { considered feasible based on indicators: typography, color, visual effects, } \\
\text { objects, and music, which reaches a score of } 4.22 \text {; (3) The opening bumper is } \\
\text { considered effective in conveying the identity of the "Bincang Santai" TV } \\
\text { program in brief, based on the average EPIC dimension achievement of } 4.59 \text {. }\end{array}$ \\
\hline
\end{tabular}

\section{Corresponding Author:}

Second Author,

Teknik Multimedia dan Jaringan, Jurusan Teknik Informatika,

Politeknik Negeri Batam,

Batam Centre, Jl. Ahmad Yani, Tlk. Tering, Kec. Batam Kota, Kepulauan Riau 29461.

Email: jonathan.elsson@gmail.com, setya4u@gmail.com

\section{PENDAHULUAN}

Dalam Undang-Undang penyiaran Indonesia, sebuah program dikenal dengan istilah "siaran” untuk menyampaikan pesan dalam berbagai macam bentuk. Terdapat dua jenis siaran atau program televisi, yaitu program informasi dan program hiburan [1]. Dalam program informasi dikenal istilah berita keras (hard news) dan berita lunak (soft news). Salah satu contoh berita lunak adalah program televisi Talkshow Bincang Santai, seperti halnya ditayangkan oleh stasiun televisi lokal iNews Batam. Stasion TV iNews merupakan bagian dari Media Nusantara Citra Group atau MNC Group yang menyajikan konten berita nasional dan daerah. Progam Bincang Santai dikategorikan sebagai berita lunak karena menyajikan informasi penting dan menarik yang disampaikan secara mendalam namun tidak harus segera ditayangkan.

Opening bumper merupakan transisi yang berada pada awal sebuah program, sebelum masuk iklan, atau bagian akhir pada sebuah program [2]. Istilah Opening Bumper atau Opening Bumper Break (OBB) merupakan animasi grafis yang berisi identitas suatu program yang biasanya berdurasi 15-30 detik [3]. Opening bumper juga dapat dimanfaatkan untuk memberikan penjelasan singkat tentang program yang akan segera ditayangkan. Opening bumper program Bincang Santai pada stasiun iNews TV Batam telah dibuat dan digunakan sejak tahun 2015 yaitu menampilkan beberapa cuplikan talkshow pada tahun 2015, namun opening bumper tidak lagi menyampaikan identitas program Bincang Santai yang dibawakan oleh host yang baru. Berkembangnya teknologi saat ini, sangat 
memungkinkan opening bumper dapat menampilkan cuplikan-cuplikan tayangan baru. Oleh sebab itu, iNews TV Batam perlu membuat opening bumper yang baru.

Salah satu jenis video opening bumper yang umum digunakan pada stasiun TV adalah bumper-in dan bumper-out dalam bentuk motion graphic [4]. Motion Graphic merupakan gabungan dari berbagai desain-desain visual bersama elemen lain seperti musik, tipografi, serta dianimasikan sehingga membuat sebuah video untuk menyampaikan pesan yang ingin disampaikan dan tampak menarik [5]. Beberapa penelitian tentang motion graphic untuk kebutuhan dan metode penelitian yang berbeda antara lain: sebagai media sosialisasi dan promosi menggunakan metode Villamil-Molina[6]; sebagai OBB Program TV menggunakan pendekatan kualitatif [3]; dan sebagai iklan layanan masyarakat dengan menerapkan metode semiotika Peirce[7]. Berdasarkan keberagaman penerapan motion graphic ini, maka dianggap cocok digunakan sebagai opening bumper program TV. Oleh karena itu, pembuatan opening bumper pada penelitian ini menerapkan motion graphic.

Terdapat 2 fokus penelitian ini yaitu membuat opening bumper dalam bentuk motion graphic dan selanjutnya menganalisis kelayakan produk berdasarkan pandangan pihak pengelola program TV dan persepsi masyarakat. Pembuatan produk(opening bumper) menggunakan pendekatan Sherwood-Rout, yang memiliki tahapan terstruktur, lengkap dan rinci serta mudah dipahami[8]. Selanjutnya analisis kelayakan oleh pihak pengelola program TV sebagai client dilakukan dalam bentuk review serta dianalisis berdasarkan persepsi masyarakat berdasarkan dimensi pada model EPIC.

\section{LANDASAN TEORI}

\subsection{Opening Bumper}

Opening bumper adalah animasi pembuka singkat yang menggambarkan identitas sebuah acara. Bumper merupakan animasi pendek yang berada pada bagian awal pada sebuah program saat pergantian dari iklan menuju program dan dapat mempengaruhi sensai persepsi manusia juga mampu mempengaruhi penonton sama halnya dengan kekuatan iklan televisi [3]. Dalam menyampaikan kesan dan pesan terhadap acara yang sedang berlangsung sehingga acara tersebut dapat dipahami dengan mudah oleh pemirsa tanpa perlu penjelasan yang panjang lebar, diperlukan unsur elemen opening bumper seperti: tipografi, warna, efek visual yang digunakan, maupun objek-objek visual, sampai musik (backsound) yang mendukung atau menghidupkan suasana [9].

\section{Tipografi}

Tipografi adalah suatu kesenian dan teknik dalam memilih dan menata huruf dengan pengaturan penyebarannya pada ruang yang tersedia untuk menciptakan kesan tertentu, dan pembaca mendapatkan kenyamanan membaca dari segi keterbacaan maupun estetika. Tipografi menekankan penggunaan bentuk huruf untuk mengkomunikasikan secara visual suatu bahasa verbal [10]. Dalam sebuah animasi bumper, hal yang perlu diperhatikan adalah legibilitas dan keterbacaan. Legibilitas adalah tingkat keterdeteksian huruf saat dipotong dengan ekstrim hingga bagian tertentu yang masih bisa dikenali. Legibilitas menentukan tingkat keterbacaan huruf dalam kondisi yang sulit seperti, gerakan dalam kecepatan tinggi, cahaya remang, dan lain-lain. Sedangkan keterbacaan adalah kemudahan suatu huruf terbaca berdasarkan susunan huruf, kerapatan huruf, besar huruf, dan kerumitan kalimat[11]. Jenis-jenis tipografi antara lain:

\section{a. Roman}

Roman adalah salah satu jenis tipografi yang mempunyai garis kecil disetiap ujung hurufnya. Dalam desain grafis, font jenis serif memiliki makna klasik, anggun, tegas, lemah gemulai dan feminim.

\section{b. Egyptian}

Egyptian memiliki ciri huruf seperti papan. Berbeda dengan Roman, ketebalan huruf Egyptian sama disemua hurufnya. Kesan yang ditimbulkan jenis huruf ini adalah kokoh, kuat, kekar, dan stabil.

c. Sans Serif

Jenis huruf Sans Serif ialah tidak memiliki sirip di ujung huruf, ketebalan hurufnya solid, tidak tipis tebal. Kesan yang ditimbulkan jenis huruf ini adalah modern, kontemporer, dan efisien.

d. Script

Ciri huruf script adalah seperti tulisan tangan sambung yang dibuat oleh pena, pensil atau kuas. Biasanya tulisan jenis ini memiliki ciri miring ke kanan. Kesan yang ditimbulkan jenis tipografi ini adalah pribadi dan akrab.

\section{e. Miscellaneous}

Huruf jenis ini tidak memiliki ciri khas yang spesifik seperti 4 jenis tipografi lainnya. Karena jenis ini merupakan pengembangn dari tipografi yamg sudah ada, hanya ditambah sedikit ornamen dan hiasan tambahan lainnya.

\section{Warna}

Warna adalah suatu cahaya yang dipantulkan suatu objek ke mata manusia. Peran warna sangat penting pada sebuah design [12]. Warna menciptakan sebuah suasana dan emosi. Warna dapat digunakan sebagai alat 
komunikasi sesuatu hal yang penting tanpa menyampaikan kata sekalipun. Warna juga dapat menimbulkan efek yang luarbiasa pada kesan desain dan cara orang meresponnya. Warna memegang peran penting untuk lebih mempertegas dan memperkuat kesan dari opening bumper tersebut. Warna juga mempunyai fungsi sebagai unsur visual untuk menjadi identitas opening bumper dari suatu acara.

3. Efek Visual

Efek visual merupakan satu bentuk menipulasi data untuk memberikan hasil yang lebih memuaskan atau lebih mengesankan. Menggunakan pemikiran yang kreatif dan menerapkan nilai estetika yang tepat, kita dapat menciptakan karya animasi yang dramatis dengan menggunakan efek-efek.

4. Objek Visual

Objek dapat menjadi simbol. Simbol terdiri dari perumpamaan metafora, untuk itu petunjuk merancang simbol yaitu menciptakan visual sederhana, menampilkan informasi atau mengekspresikan makna, menciptakan sebuah tanda yang berbeda, menciptakan desain yang mudah dikenali dengan cepat, dan mendesain sebuah simbol yang sesuai dengan ide yang disajikan.

\section{Backsound}

Backsound atau suara latar dapat mendukung visual dalam sebuah opening bumper, sehingga kesan dan pesan visual dalam video semakin menonjol. Backsound musik dapat mempengaruhi emosi manusia. Backsound juga memberi ciri khas pada suatu opening bumper [13].

Salah satu contoh opening bumper pada program talk show adalah opening bumper program Mata Najwa Trans7 [14]. Opening bumper Mata Najwa dapat dikatakan sederhana namun telah menyampaikan pesan yang baik. Opening bumper Mata Najwa berbentuk life video dengan efek visual berdurasi 27 detik. Opening bumper tersebut telah digunakan selama 2 tahun terakhir di setiap episode yang tayang setiap minggu. Dalam opening bumper Mata Najwa, Najwa Shihab sebagai pembawa acara (host) yang menjadi fokus utamanya. Suasana yang disampaikan adalah Najwa Shihab berdiri di tengah-tengah gedung perkotaan dan diantara masyarakat. Terlihat dari tatapan Najwa Shihab yang tajam membawa kesan tegas dan berwibawa. Elemen opening bumper yang digunakan pada opening bumper Mata Najwa Trans7 adalah:

a. Teks yang ditampilkan pada opening bumper tersebut tidak banyak, mengingat dengan melihat pengalaman seorang Najwa Shihab dibidang jurnalis berita, masyarakat dapat mengetahui secara garis besar konten program Mata Najwa.

b. Efek visual berupa teknologi berwarna biru yang memberi kesan informasi yang didapat adalah informasi yang terkini.

c. Backsound pada opening bumper Mata Najwa merupakan musik semangat yang menciptakan kesan cerdas dan berani. Kesan tersebut sesuai dengan konten program Mata Najwa Trans7 yang dengan cerdas, tegas, dan berani dalam menyajikan sebuah program talk show. Backsound tersebut menjadi identitas program Mata Najwa Trans7

Sementara OBB Bincang Santai di iNews Batam dikemas dalam jenis acara talkshow yang informatif. Program Bincang Santai tayang dengan durasi 60 menit yang terdiri dari lima segmen dan dikategorikan R-BO (RemajaBimbingan Orang Tua). Seperti namanya, program Bincang Santai dibawakan dengan wawancara yang santai antara narasumber dengan pemandu acara namun tetap menyampaikan informasi, edukasi, dan inspirasi. Salah satu bagian program TV Bincang Santai ini adalah OBB (Opening Bumper Break). Opening bumper Bincang Santai sudah dibuat sejak tahun 2015. Hal ini membuat opening bumper yang menjadi identitas suatu program telah ketinggalan zaman, karena opening bumper tersebut menampilkan cuplikan-cuplikan video episode yang tayang pada tahun 2015 atau sebelumnya. Opening Bumper Bincang Santai memiliki konsep animasi 3D dengan gaya warna merah monochromatic untuk menyampaikan kesan yang santai dan harmoni. Audio yang digunakan adalah Serve Hot oleh Joi Veer. Kelebihan opening bumper ini adalah visual yang dinamis, sedangkan kekurangan nya pada masa sekarang adalah desain kurang menarik dan cuplikan video menampilkan pembawa acara yang lama.

\subsection{Motion Graphic}

Motion graphic adalah gabungan dari potongan elemen-elemen desain/animasi yang berbasis pada media visual yang menggabungkan bahasa film dengan desain grafis, dengan memasukkan elemen yang berbeda-beda seperti 2D atau 3D [2]. Motion graphic merupakan media visual yang menggabungkan film dan desain grafis sehingga menciptakan ilusi dari gerak [15]. Terdapat beberapa unsur elemen yang dapat dijadikan motion graphic seperti animasi 2D dan 3D, objek visual, video, film, tipografi, ilustrasi, fotografi, dan musik. Terdapat beberapa pembagian visual yang dapat menghasilkan motion graphic secara efektif namun tetap menarik [2] antara lain:

1. Space, terdiri dari arah, ukuran, arah acuan, arah gerakan, perubahan ketika gerakan dipengaruhi gerakan lain, hubungan pergerakan terhadap batas-batas frame.

2. Temporial, terdiri dari time dan velocity. 
3. Live action, faktor-faktor yang perlu diperhatikan ketika bekerja dengan konten live action termasuk bentuk atau konteks, property film, dan sifat sinematik, seperti tone, contrast, lighting, depth of field, focus, camera angle, shot size, dan mobile framing.

4. Typographic Type, merupakan salah satu prinsip untuk membangun sebuah persen dalam desain grafis. Dalam penggunaan type terdapat beberapa hal yang bisa dimanfaatkan sesuai dengan kebutuhan, misalnya tipe huruf, ukuran weight, capital or lowercase.

Secara umum, proses pembuatan (development) motion graphic memiliki beberapa tahap antara lain: tracing, coloring, animating, dubbing, editing, dan rendering. Masing-masing tahapan ini dilakukan secara sekuensial atau berurutan, kecuali pada proses animating dan dubbing. Proses animating dan dubbing dapat saling mendahului, tergantung pada kebutuhan tahapan selanjutnya [16]. Sementara, berdasarkan pengalaman lain [6], memiliki 2 tahapan antara lain:

1. Digitalisasi Gambar (Tracing dan Coloring), gambar pada kertas di-scan kemudian di-tracing. Hasil dari tracing diberikan warna. Tahap ini dilakukan menggunakan tools seperti: software Adobe Illustrator atau software desain lainnya.

2. Compositing dan Animating, gambar digital digabungkan menjadi suatu kesatuan komposisi, kemudian gambar tersebut diberi gerakan sehingga menjadi suatu animasi.

\section{METODE PENELITIAN}

Pembuatan opening bumper menggunakan metode pengembangan oleh Sherwood-Rout yang memiliki 6 tahapan antara lain: Project Initiation, Specifications, Design, Production, Review and Evaluation, dan Delivery and Implemetation. Selanjutnya produk akan dianalisis kelayakannya sebagai opening bumper program Bincang Santai iNews Batam berdasarkan indikator sebuah opening bumper dalam bentuk motion graphic, sedangkan analisis persepsi khalayak menggunakan analisa model EPIC. Kedua hasil analisis diukur berdasarkan skala Likert. Tahapan penelitian diilustrasikan pada Gambar 1.

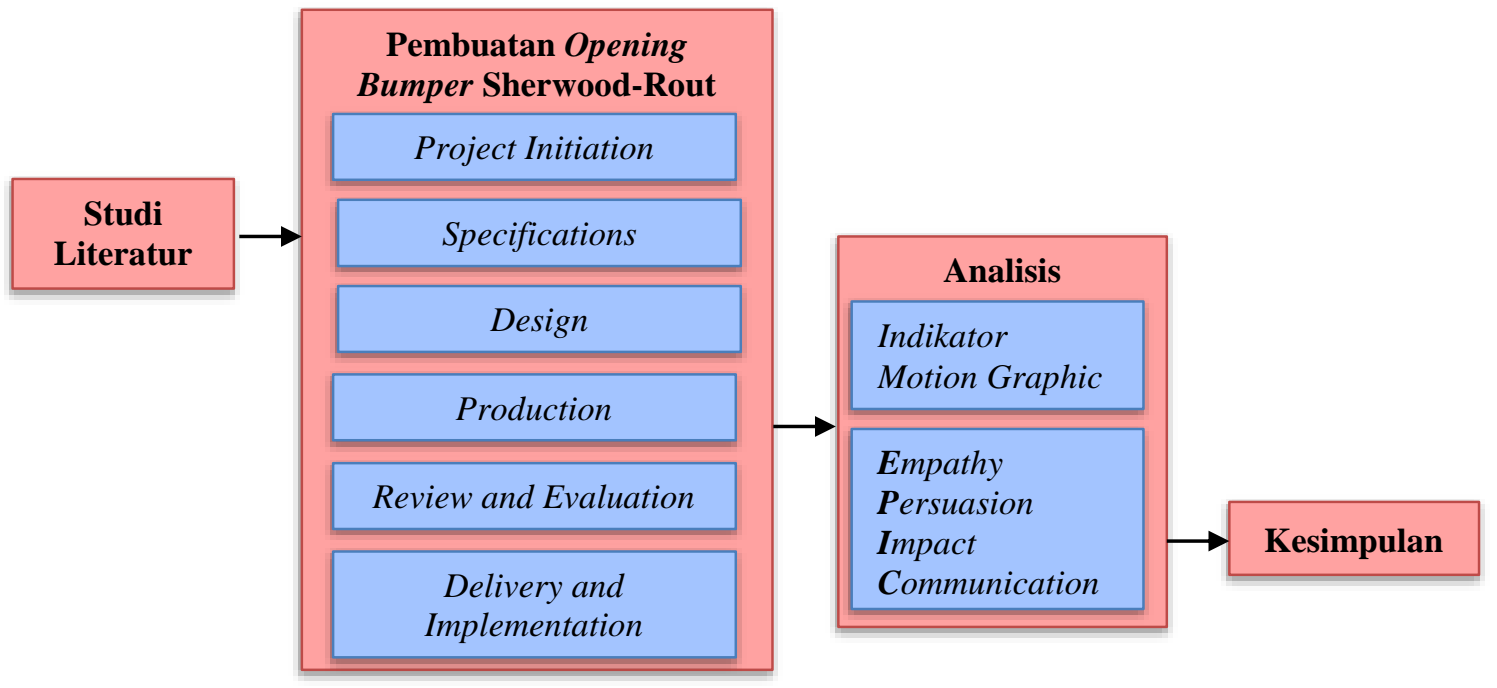

Gambar 1. Tahapan Penelitian

\subsection{Studi Literatur}

Tahapan ini dilakukan pembelajaran dan studi literatur menggunakan beberapa referensi, studi pustaka dan pengumpulan data-data melalui media-media online dan INews TV Batam, seperti diuraikan pada bagian landasan teori.

\subsection{Pembuatan Opening Bumper}

Pembuatan produk berupa opening bumper dalam bentuk motion graphic menggunakan pendekatan SherwoodRout [8] sebagai berikut:

\section{Project Initiation}

Tahapan ini berfokus pada perencanaan yang dibutuhkan untuk pengembangan produk antara lain: penentuan strategi dan konsep secara menyeluruh, penghitungan anggaran termasuk biaya yang berhubungan dengan 
hak cipta maupun penggunaan lisensi, dan pengidentifikasian cakupan manajemen resiko (bisnis, teknis, dan resiko proyek) bila dibutuhkan.

Opening bumper dibuat dalam bentuk motion graphic dengan penggabungan live video. Live video diambil dari cuplikan episode-episode Bincang Santai sebelumnya. Audio yang digunakan berupa backsound music yang memiliki lisensi free, dalam artian dapat digunakan oleh siapa saja tanpa perlu ragu akan penyalahgunaan hak cipta. Hal ini membuat biaya yang berhubungan dengan hak cipta tidak ada. Strategi pengerjaan proyek dapat berupa timeline kerja yang menjadi acuan waktu pengerjaan, sehingga produk dapat diselesaikan dengan maksimal dan tepat waktu.

\section{Specifications}

Pada tahapan ini, penilaian ulang (reassessed) kelayakan proyek, yaitu pengembangan spesifikasi rinci dari fungsi, persyaratan kinerja (jika ada), konten, dan tujuan proyek, penentuan kriteria pengujian dan kegunaan (usability).

a. Spesifikasi Rinci dari Fungsi Produk adalah elemen opening bumper berbentuk motion graphic yang digabungkan dengan video-video cuplikan program TV Bincang Santai. Produk yang dihasilkan berdurasi 18 detik dengan format (*.mpg) yaitu format digital audio dan video untuk kualitas siaran. Opening bumper harus memiliki background musik yang menyenangkan sesuai dengan konten program TV Bincang Santai iNews Batam.

b. Opening bumper yang dihasilkan digunakan untuk opening bumper program TV Bincang Santai iNews Batam yang menjadi identitas program Bincang Santai iNews Batam, sehingga ada penggunaan asset-aset INews Batam TV seperti logo, warna dominan dan ciri khas lainnya.

c. Konten opening bumper berisi beberapa cuplikan program TV Bincang Santai iNews Batam yang telah tayang sebelumnya dan kata-kata yang mewakili program TV Bincang Santai iNews Batam.

d. Penentuan spesifikasi perangkat hardware dan software. Pembuatan opening bumper menggunakan PC/Laptop dengan spesifikasi menggunakan referensi media digital, dan software yang mendukung proses pembuatan motion graphic, editing, dan rendering seperti Adobe Illustrator CC 2017, Adobe After Effects CC 2017, dan Adobe Premiere Pro CC 2017.

e. Pengujian dilakukan untuk review hasil pada setiap tahapan, kemudian produk direview apakah sudah layak digunakan sebagai opening bumper di INews TV Batam atau tidak. Review dilakukan oleh ahli dan profesional multimedia dan broadcasting dari pihak INews TV Batam. Kriteria penilaian (review) berdasarkan indikator elemen-elemen opening bumper antara lain: yaitu tipografi, warna, efek visual, objek visual, dan musik (backsound). Kelayakan Produk juga dianalisis berdasarkan persepsi masyarakat secara online, menggunakan dimensi model EPIC yaitu Empathy, Persuasion, Impact, dan communication.

\section{Design}

Tahapan ini menghasilkan rancangan atas kebutuhan dan usulan dari client. Design pada opening bumper ini berupa storyboard yaitu kumpulan sketsa gambar yang disusun berurutan dan disesuaikan dengan naskah dan konsep. Video bumper terdiri atas lima scene dan berdurasi 18 detik. Audio pada opening bumper menggunakan backsound musik berjudul Hawaiian Weekend oleh Igor Khainskyi yang didapat melalui Youtube channel Audio Library. Audio hanya menggunakan backsound musik tanpa menggunakan dialog maupun suara dari cuplikan video. Tipografi yang digunakan berjenis Sans Serif karena memberi kesan sederhana. Efek visual yang ditampilkan akan berupa transisi dan pergerakan objek tiap scene. Tayangan program memiliki ciri khas warna utama yang menjadi identitas program tersebut [11]. Warna merah muda melambangkan keromantisan, kelembutan, kasih sayang, cinta, dan feminism [12]. Dengan demikian komposisi warna yang digunakan didominasi warna merah muda sama seperti opening bumper Bincang Santai iNews Batam sebelumnya, selain menjadi identitas warna program Bincang Santai, juga untuk menyampaikan kesan yang lembut dan santai. Kode warna yang digunakan yaitu: \#010A43, \#FFC2C2, \#FF9D9D, dan \# FF2E63. Storyboard ditampilkan pada Tabel 1. 
Tabel 1. Storyboard

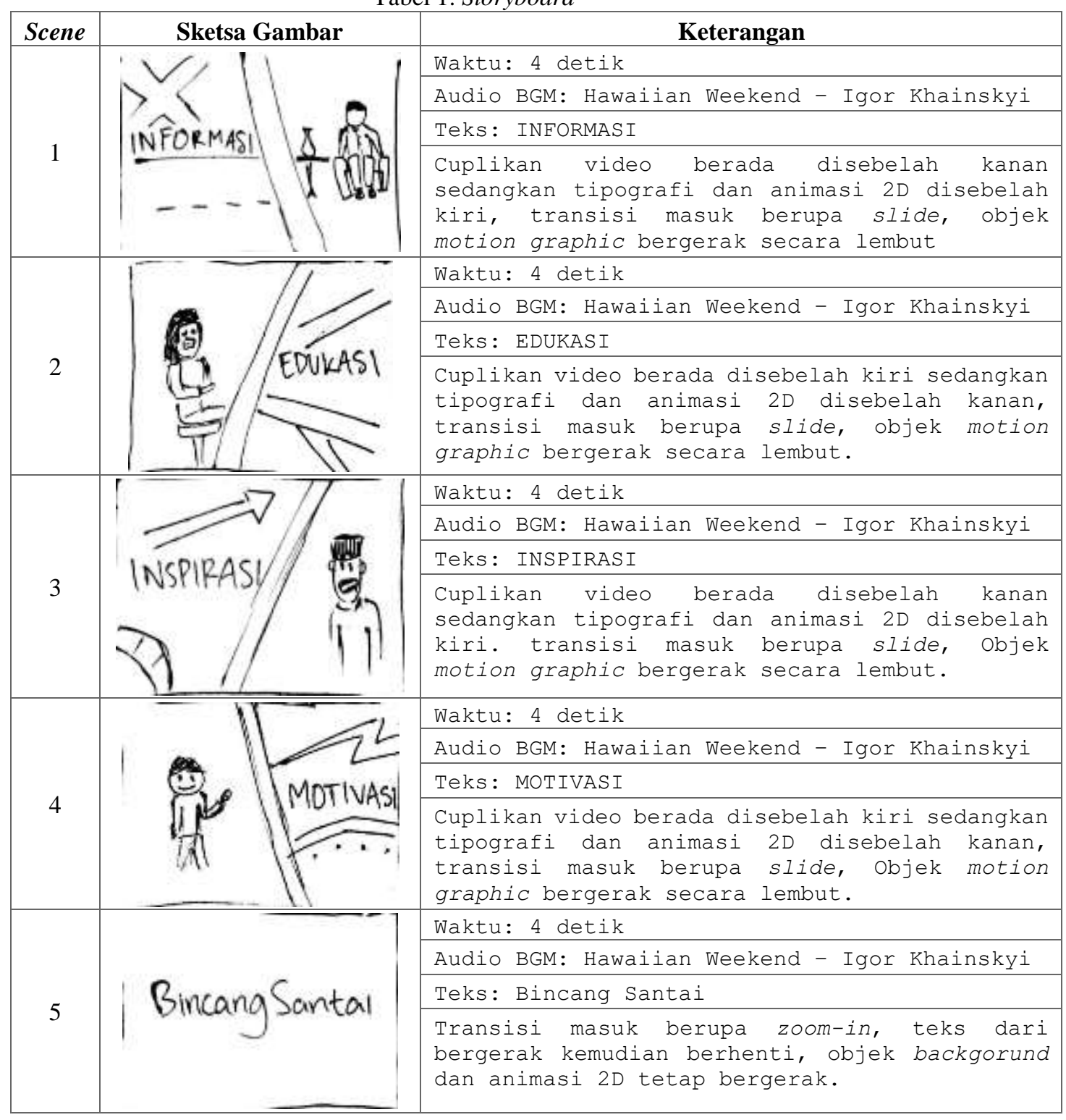

\section{Production}

Tahap ini merupakan penggunaan dengan menggabungkan bahan-bahan yang sudah ditentukan. Tahap ini merupakan proses penggabungan bahan-bahan berdasarkan konsep awal dan storyboard yang dibuat menggunakan software Adobe Illustrator CC 2017, Adobe After Effects CC 2017, dan Adobe Premiere Pro CC 2017. Proses produksi meliputi pembuatan objek animasi, editing, dan rendering.

a. Pembuatan objek animasi

Objek animasi akan diletakkan pada ruang kosong sehingga bagian tersebut tidak lagi terlihat kosong. Objek animasi dibuat menggunakan software Adobe Illustrator CC 2017. Objek yang dibuat berbentuk persegi, silang, gelombang, garis, segitiga, dan lingkaran. Obejk tersebut diexport dengan format .png.

b. Editing

Proses editing diawali dengan penggabungan video-video cuplikan. Kemudian backsound music disunting menjadi 18 detik sesuai dengan kebutuhan. Seluruh scene digabungkan sesuai urutan beserta transisi antar scene dan backsound music. Objek animasi yang telah dibuat diletakkan pada posisi yang masih dirasa kosong.

c. Rendering

Pada tahap ini, dilakukan proses render untuk menciptakan hasil akhir berupa video dengan format .mpg. Proses render menggunakan software Adobe Premiere Pro CC 2017. Proses tersebut membutuhkan waktu selama 25 detik. 


\section{Review and Evaluation}

Tahapan ini selalu ada di seluruh tahapan proses pengembangan. Produk selalu diperiksa pada setiap akhir tahapan konseptualisasi, spesifikasi, rancangan dan produksi sebelum memulai tahapan selanjutnya.

\section{a. Review Berdasarkan Storyboard oleh Pengembang}

Review ini dilakukan oleh pengembang, untuk memastikan rancangan dan konsep telah diimplementasikan. Dokumen pengujian produk berdasarkan storyboard ditampilkan pada Tabel 2.

Tabel 2. Dokumen pengujian produk berdasarkan storyboard

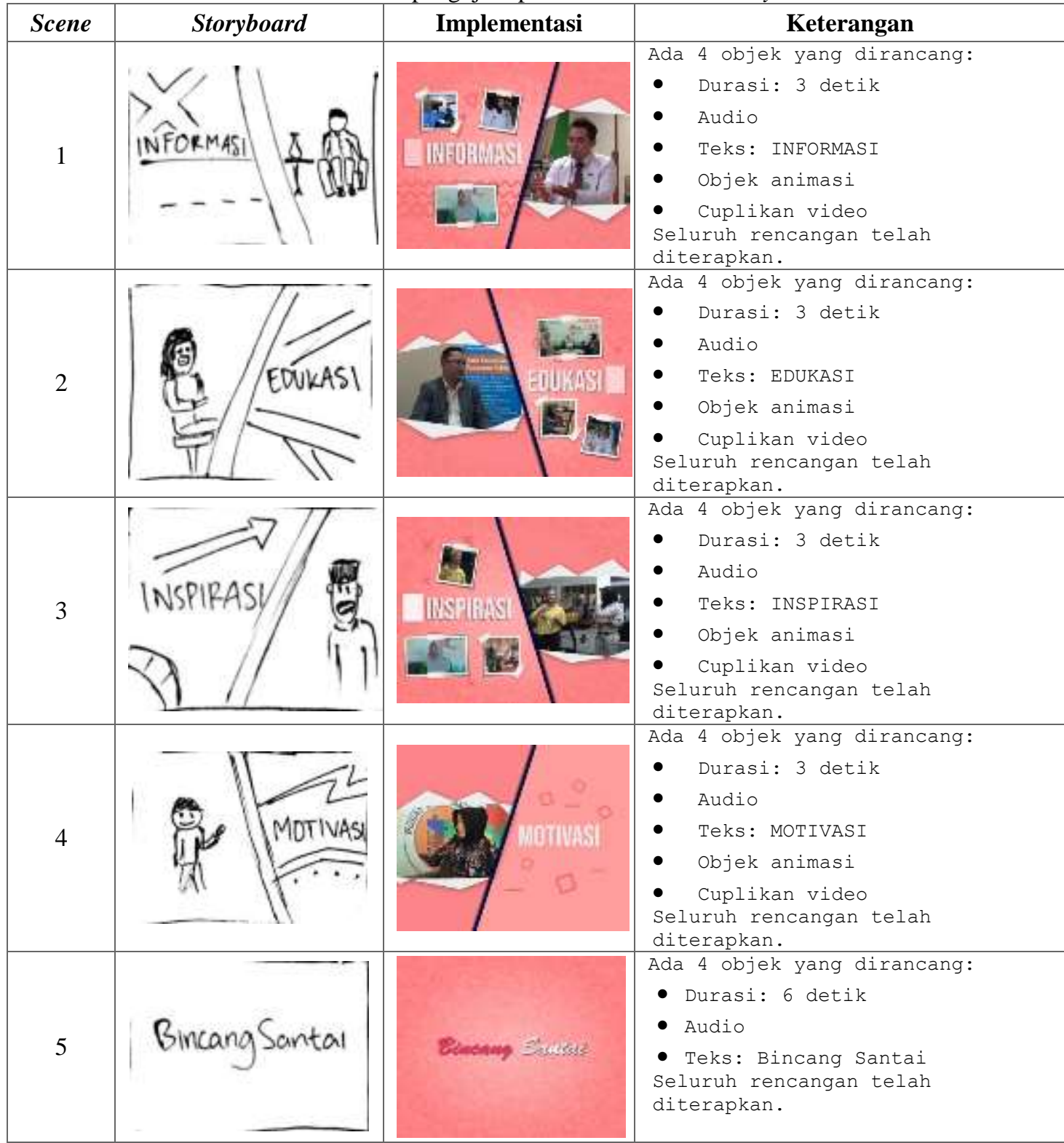

\section{b. Review dan evaluasi oleh client}

opening bumper diberikan kepada client sebagai Koordinator Editor untuk review dan evaluasi sehingga dapat memenuhi permintaan. Revisi dilakukan jika hasil review dan evaluasi mengharuskan untuk dilakukan revisi produk. Beberapa hasil review dan evaluasi oleh client ditunjukkan pada Tabel 3. 
Tabel 3. Hasil review dan evaluasi oleh client

\begin{tabular}{|c|c|c|c|}
\hline Scene & Sebelum & Sesudah & Keterangan \\
\hline 1 & & & $\begin{array}{l}\text { - Menambahkan tekstur dan gradasi } \\
\text { pada backgound } \\
\text { Menambahkan } 3 \text { cuplikan video } \\
\text { dengan konsep polaroid }\end{array}$ \\
\hline 2 & & & $\begin{array}{l}\text { - Menambahkan tekstur dan gradasi } \\
\text { pada backgound } \\
\text { Menambahkan } 3 \text { cuplikan video } \\
\text { dengan konsep polaroid }\end{array}$ \\
\hline 3 & & & $\begin{array}{l}\text { - Menambahkan tekstur dan gradasi } \\
\text { pada backgound } \\
\text { Menambahkan } 3 \text { cuplikan video } \\
\text { dengan konsep polaroid }\end{array}$ \\
\hline 4 & & & $\begin{array}{l}\text { - Menambahkan tekstur dan gradasi } \\
\text { pada backgound } \\
\text { Menambahkan } 3 \text { cuplikan video } \\
\text { dengan konsep polaroid }\end{array}$ \\
\hline 5 & Sinen $y=x$ & 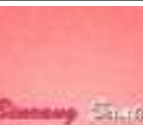 & $\begin{array}{l}\text { - Menambahkan tekstur dan gradasi } \\
\text { pada backgound }\end{array}$ \\
\hline
\end{tabular}

\section{Delivery and Implementation}

Tahap terakhir ialah mengirimkan produk pada client untuk digunakan. Kemudian keseluruhan pelaksanaan proyek ditinjau ulang dengan perbaikan-perbaikan yang direkomendasikan. Di tahap akhir, opening bumper disimpan kedalam perangkat keras HDD sebagai tempat penyimpanan. Penggunaan video opening bumper akan diterapkan pada episode Program Bincang Santai iNews Batam yang selanjutnya. Bersamaan dengan pendistribusian ini sekaligus juga dilakukan penggalian data respon dari khalayak.

\subsection{Analisis Produk (Opening Bumper)}

Analisis produk dibagi menjadi 2 bagian yaitu analisis kelayakan produk sebagai opening bumper dan analisis efektivitas produk berdasarkan persepsi responden. Tahapan analisis yang dilakukan divisualisasikan pada gambar 2 .
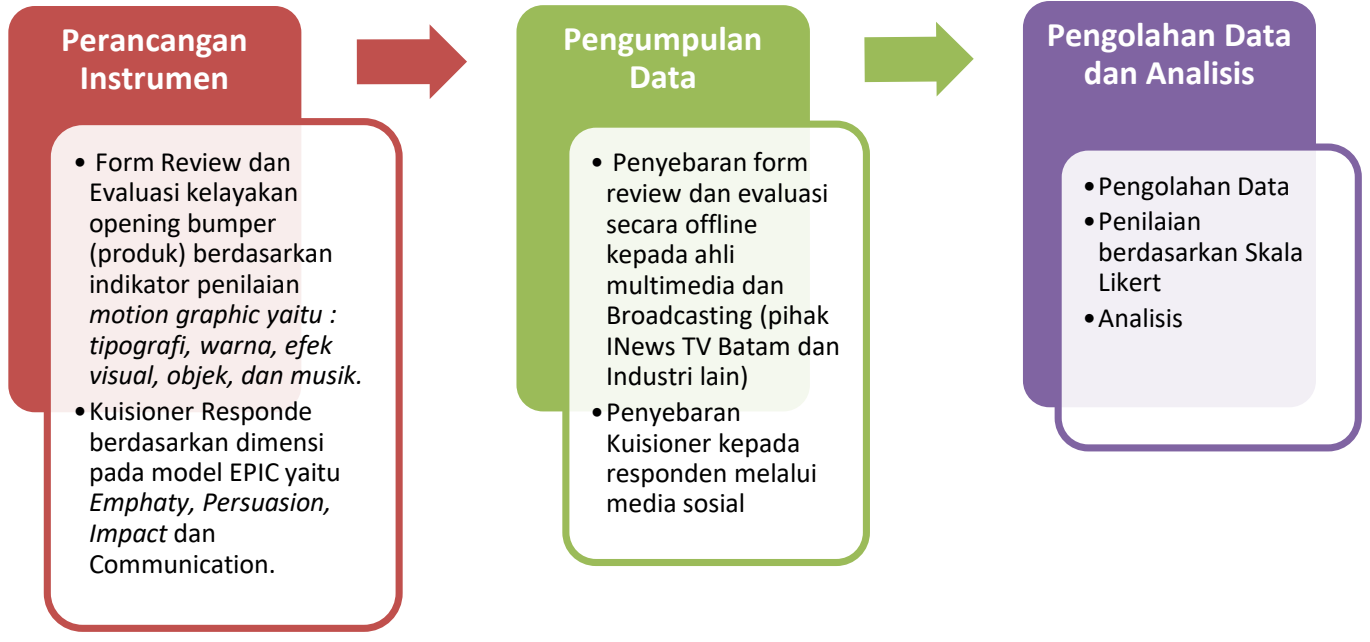

Gambar 2. Tahapan Proses Analisis Opening Bumper INews TV Batam 


\section{HASIL DAN PEMBAHASAN}

\subsection{Analisis Kelayakan Produk Sebagai Opening Bumper di INews TV Batam}

Jumlah responden yang melakukan evaluasi produk ada 5 ahli yang berasal dari industri dan pihak INews TV Batam. Hasil olahan data disajikan pada Tabel 4.

Tabel 4. Hasil perolehan data uji kelayakan produk

\begin{tabular}{|c|c|c|c|c|c|c|c|}
\hline \multirow{2}{*}{ No } & \multirow{2}{*}{ Indikator } & \multicolumn{5}{|c|}{ Frekuensi } & \multirow{2}{*}{$\begin{array}{l}\text { Total } \\
\text { Nilai }\end{array}$} \\
\hline & & SS & $\mathbf{S}$ & CS & TS & STS & \\
\hline 1 & Kesesuaian objek gambar & 0 & 5 & 0 & 0 & 0 & 20 \\
\hline 2 & Kesesuaian cuplikan video & 3 & 2 & 0 & 0 & 0 & 23 \\
\hline 3 & Kesesuaian pemilihan kata & 1 & 3 & 1 & 0 & 0 & 20 \\
\hline 4 & Kesesuaian backsound music & 4 & 1 & 0 & 0 & 0 & 24 \\
\hline 5 & Kesesuaian transisi & 1 & 3 & 1 & 0 & 0 & 20 \\
\hline 6 & Kesesuaian font & 0 & 3 & 2 & 0 & 0 & 18 \\
\hline 7 & Kesesuaian kombinasi warna & 2 & 3 & 0 & 0 & 0 & 22 \\
\hline 8 & Kesesuaian durasi video & 2 & 3 & 0 & 0 & 0 & 22 \\
\hline \multicolumn{2}{|c|}{$\begin{array}{l}\text { Total Nilai = } \\
\text { (Frekuensi x Bobot Skor) }\end{array}$} & 65 & 92 & 12 & 0 & 0 & \\
\hline
\end{tabular}

Total Nilai pada tabel 4, diperoleh berdasarkan perhitungan penilaian Sangat Sesuai (SS), Sesuai (S), Cukup Sesuai (CS), Tidak Sesuai (TS), dan Sangat Tidak Sesuai (STS) yang memiliki bobot skor masing-masing: 5, 4, 3, 2, dan 1. Berdasarkan hal ini, maka diperoleh bahwa nilai tertinggi pada indikator kesesuaian backsound musik yaitu 24 poin, sedangkan ter-rendah terdapat pada indikator kesesuaian font sebesar 18 poin.

Secara keseluruhan indikator diperoleh nilai rata-rata melalui formula:

$$
\begin{aligned}
\text { Perhitungan nilai rata-rata } & =\text { Total Nilai/ }(\text { Jumlah pertanyaan } \times \text { Jumlah responden }) \\
& =169 /(5 \times 8) \\
& =4.22
\end{aligned}
$$

Nilai rata-rata yang diperoleh sebesar 4,22, kemudian divisualisasikan ke dala peta skala Likert seperti ditunjukkan pada gambar 3.

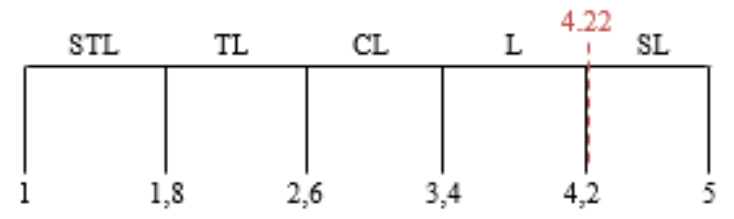

Gambar 3. Skala uji kelayakan Opening Bumper

Berdasarkan peta skala uji kelayakan pada gambar 3, menunjukkan bahwa produk opening bumper Bincang Santai iNews TV Batam termasuk dalam kategori Sangat Layak (SL) sehingga layak digunakan sebagai opening bumper Bincang Santai iNews TV Batam.

\subsection{Analisis Efektifitas Produk Sebagai Opening Bumper oleh Persepsi Responden}

Analisis efektifitas opening bumper menggunakan dimensi pada model EPIC yaitu empati, persuasi, dampak, dan komunikasi. Instrumen pengumpulan data dalam bentuk kuisioner dan video opening bumper dibagikan secara online melalui media sosial sehingga diperoleh responden yang mengisi ada sejumlah 41 responden dengan rentang

\begin{tabular}{|c|c|c|c|c|c|c|c|c|c|}
\hline \multirow[t]{2}{*}{ No } & \multirow[t]{2}{*}{ Dimensi } & \multirow[t]{2}{*}{ Pernyataan } & \multicolumn{5}{|c|}{ Frekuensi } & \multirow{2}{*}{$\begin{array}{c}\text { Rata-rata } \\
\text { (Frekuensi } \\
\text { x Bobot) } \\
\end{array}$} & \multirow[t]{2}{*}{ Persentase } \\
\hline & & & SS & $\mathbf{S}$ & CS & TS & STS & & \\
\hline \multirow{2}{*}{1} & \multirow{2}{*}{$\begin{array}{l}\text { Empathy } \\
\text { (Empati) }\end{array}$} & $\begin{array}{l}\text { Anda menyukai opening bumper Bincang } \\
\text { Santai iNews Batam. }\end{array}$ & 27 & 13 & 1 & 0 & 0 & 4.63 & $92.7 \%$ \\
\hline & & $\begin{array}{l}\text { Opening bumper Bincang Santai iNews } \\
\text { Batam menarik. }\end{array}$ & 29 & 11 & 1 & 0 & 0 & 4.68 & $93.7 \%$ \\
\hline
\end{tabular}
usia 15 tahun ke atas. Hasil perolehan data disajikan pada Tabel 5.

Tabel 5. Hasil perolehan data responden 


\begin{tabular}{|c|c|c|c|c|c|c|c|c|c|}
\hline \multirow{2}{*}{2} & \multirow{2}{*}{$\begin{array}{l}\text { Persuasio } \\
\quad n \\
\text { (Persuasi) }\end{array}$} & $\begin{array}{l}\text { Anda tertarik dengan program TV } \\
\text { Bincang Santai iNews Batam. }\end{array}$ & 27 & 13 & 1 & 0 & 0 & 4.63 & $92.7 \%$ \\
\hline & & $\begin{array}{l}\text { Anda ingin menyasikan program TV } \\
\text { Bincang Santai iNews Batam. }\end{array}$ & 23 & 16 & 2 & 0 & 0 & 4.51 & $90.2 \%$ \\
\hline \multirow{2}{*}{3} & \multirow{2}{*}{$\begin{array}{l}\text { Impact } \\
\text { (Dampak) }\end{array}$} & $\begin{array}{l}\text { Anda mendapat informasi tentang } \\
\text { program TV Bincang Santai iNews } \\
\text { Batam. }\end{array}$ & 28 & 12 & 1 & 0 & 0 & 4.65 & $93.2 \%$ \\
\hline & & $\begin{array}{l}\text { Anda akan merekomendasikan teman atau } \\
\text { keluarga untuk menyaksikan program TV } \\
\text { Bincang Santai iNews Batam. }\end{array}$ & 20 & 16 & 4 & 1 & 0 & 4.34 & $86.8 \%$ \\
\hline \multirow[b]{2}{*}{4} & \multirow{2}{*}{$\begin{array}{l}\text { Communi } \\
\text { cation } \\
\text { (Komunik } \\
\text { asi) }\end{array}$} & $\begin{array}{l}\text { Informasi tentang program TV Bincang } \\
\text { Santai iNews Batam mudah dimengerti. }\end{array}$ & 29 & 10 & 2 & 0 & 0 & 4.65 & $93.2 \%$ \\
\hline & & $\begin{array}{l}\text { Opening bumper Bincang Santai iNews } \\
\text { Batam sebagai opening program TV } \\
\text { Bincang Santai iNews Batam mudah } \\
\text { diingat. }\end{array}$ & 30 & 9 & 2 & 0 & 0 & 4.68 & $93.7 \%$ \\
\hline
\end{tabular}

1) Dimensi empathy menggambarkan produk disukai oleh responden atau tidak dan hubungan pribadi responden terhadap produk tersebut. Berdasarkan dimensi empati pada tabel 2, dapat menunjukkan kesukaan responden terhadap video opening bumper pada program Bincang Santai. Pernyataan diwakili oleh E1 dan E2 dengan perolehan sebagai berikut:

E1: Diperoleh bahwa terdapat 3 skala yang diisi oleh responden, yaitu skala Sangat Setuju (SS) dengan presentase $65.9 \%$ (27 orang), Setuju (S) dengan presentase 31.7\% (13 orang), dan Cukup Setuju (CS) dengan presentase $2.4 \%$ (1 orang).

E2: Diperoleh bahwa terdapat 3 skala yang diisi oleh responden, yaitu skala Sangat Setuju (SS) dengan presentase $70.7 \%$ (29 orang), Setuju (S) dengan presentase 26.8\% (11 orang), dan Cukup Setuju (CS) dengan presentase $2.4 \%$ ( 1 orang).

Diperoleh nilai rata-rata dimensi empathy adalah 4,65. Nilai yang digambarkan pada peta skala untuk menentukan keefektifan produk seperti ditunjukkan pada Gambar 3, artinya kategori empati sangat efektif sehingga responden menyukai video opening bumper.

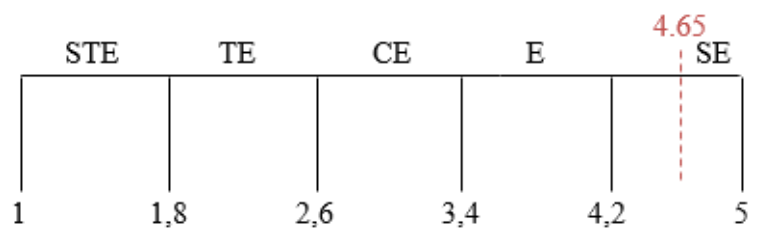

Gambar 3. Skala dimensi Empathy

2) Dimensi persuasion menginformasikan bagaimana produk yang dibuat dapat menguatkan para responden dapat mengetahui bagaimana dampak yang dihasilkan dari produk untuk menggunakannya. Berdasarkan dimensi persuasi pada table 2, dapat menggambarkan ketertarikan responden terhadap video opening bumper pada program Bincang Santai sehingga akan menonton acara tersebut sesuai jadwal tayangnya. Pernyataan diwakili oleh P1 dan P2 dengan perolehan nilai sebagai berikut:

P1 : Diperoleh bahwa terdapat 3 skala yang diisi oleh responden, yaitu skala Sangat Setuju (SS) dengan presentase $65.9 \%$ (27 orang), Setuju (S) dengan presentase 31.7\% (13 orang), dan Cukup Setuju (CS) dengan presentase $2.4 \%$ (1 orang).

P2: Diperoleh bahwa terdapat 3 skala yang diisi oleh responden, yaitu skala Sangat Setuju (SS) dengan presentase $56.1 \%$ (23 orang), Setuju (S) dengan presentase 39\% (16 orang), dan Cukup Setuju (CS) dengan presentase $4.9 \%$ (2 orang).

Diperoleh nilai rata-rata dimensi Persuasi adalah 4,57 yang digambarkan pada peta skala untuk menentukan keefektifan produk seperti yang ditunjukkan pada Gambar 4, artinya responden tertarik terhadap program bintang Santai di INews TV Batam. 


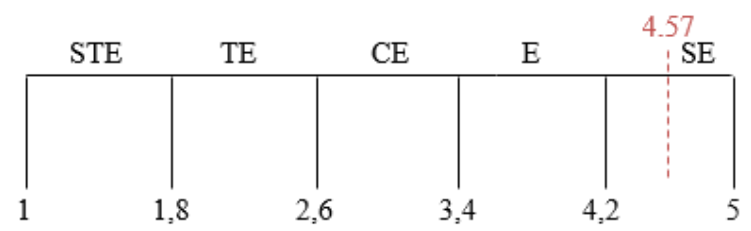

Gambar 4. Skala dimensi Persuasion

3) Dimensi impact menggambarkan keterlibatan responden terhadap penyebaran informasi yang disampaikan pada video opening bumper program Bincang Santai dan merekomendasikan kepada yang lain. Pernyataan diwakilkan oleh I1 dan I2 dengan perolehan nilai adalah sebagai berikut:

I1: Diperoleh bahwa terdapat 3 skala yang diisi oleh responden, yaitu skala Sangat Setuju (SS) dengan presentase $68.3 \%$ (28 orang), Setuju (S) dengan presentase 29.3\% (12 orang), dan Cukup Setuju (CS) dengan presentase $2.4 \%$ (1 orang).

I2: Diperoleh bahwa terdapat 4 skala yang diisi oleh responden, yaitu skala Sangat Setuju (SS) dengan presentase $48.8 \%$ (20 orang), Setuju (S) dengan presentase 39\% (16 orang), Cukup Setuju (CS) dengan presentase $9.8 \%$ (4 orang), dan Tidak Setuju (TS) dengan presentase $2.4 \%$ (1 orang).

Diperoleh nilai rata-rata dimensi impact adalah 4,49, yang digambarkan pada peta skala untuk menentukan keefektifan produk seperti yang ditunjukkan pada Gambar 5, artinya responden ikut terlibat dalam penyebaran informasi tentang program Bincang Santai pada INews TV Batam dan merekomendasikan sebagai tontonan yang baik untuk masyarakat.

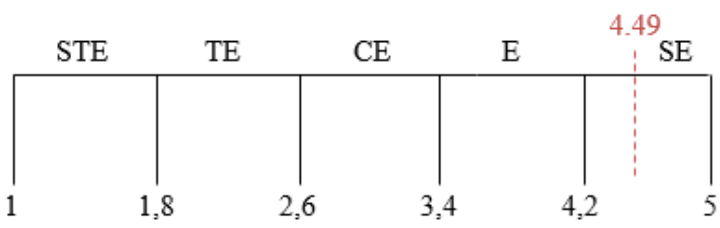

Gambar 5. Skala dimensi Impact

4) Dimensi Communication dapat memberikan informasi terhadap bagaimana responden memiliki kemampuan dalam mengingat pesan utama dari produk dan tingkat pemahamannya, sehingga melalui data pada table 2, dimensi komunikasi menunjukkan pesan atau informasi opening bumper pada Bincang Santai INews TV Batam. Pernyataan diwakilkan oleh $\mathrm{C} 1$ dan $\mathrm{C} 2$ dengan perolehan nilai adalah sebagai berikut:

C1: Diperoleh bahwa terdapat 3 skala yang diisi oleh responden, yaitu skala Sangat Setuju (SS) dengan presentase $70.7 \%$ (29 orang), Setuju (S) dengan presentase 24.4\% (10 orang), dan Cukup Setuju (CS) dengan presentase $4.9 \%$ ( 2 orang).

C2: Diperoleh bahwa terdapat 3 skala yang diisi oleh responden, yaitu skala Sangat Setuju (SS) dengan presentase $73.2 \%$ (30 orang), Setuju (S) dengan presentase 22\% (9 orang), dan Cukup Setuju (CS) dengan presentase $4.9 \%$ ( 2 orang).

Diperoleh nilai rata-rata dimensi communication adalah 4,66, yang digambarkan pada peta skala untuk menentukan keefektifan produk seperti yang ditunjukkan pada gambar 6, artinya dimensi komunikasi masuk dalam kategori sangat efektif (SE) sehingga produk opening bumper dapat menyampaikan pesan dan informasi kepada responden.

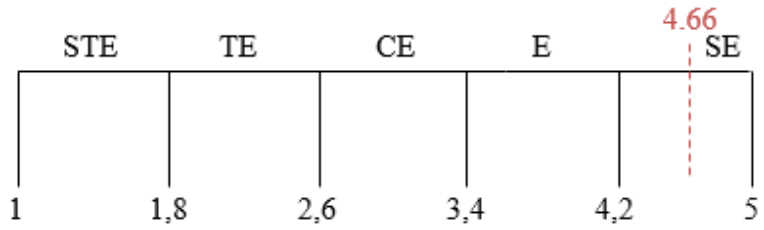

Gambar 6. Skala dimensi Komunikasi

Berdasarkan hasil perolehan untuk semua dimensi EPIC model, semua dimensi masuk dalam kategori "sangat 
efektif” seperti disajikan pada table 6 dan divisualisasikan dalam bentuk grafik pada gambar 7 .

Tabel 6. Kategori dimensi EPIC

\begin{tabular}{|c|c|c|}
\hline Dimensi & Rata-rata & Kategori \\
\hline Empathy (empati) & 4.65 & Sangat Efektif \\
\hline Persuasion (persuasi) & 4.57 & Sangat Efektif \\
\hline Impact (dampak) & 4.49 & Sangat Efektif \\
\hline Communication (komunikasi) & 4.66 & Sangat Efektif \\
\hline
\end{tabular}

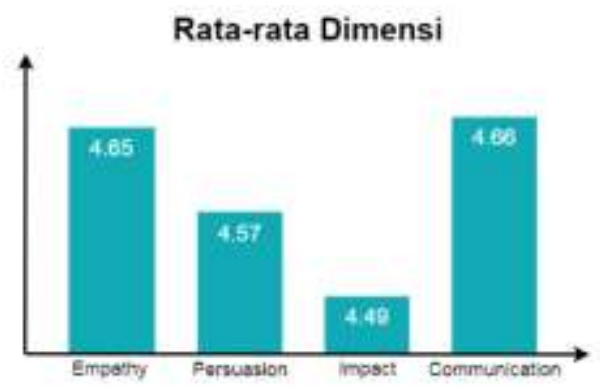

Gambar 7. Diagram rata-rata tiap dimensi

Secara keseluruhan dimensi, diperoleh EPIC rate dengan rata-rata 4,59 seperti divisualisasikan pada peta skala pada gambar 8, menunjukkan bahwa opening bumper pada program Bincang Santai INews TV Batam sangat efektif dan cocok digunakan sebagai penyampaian singkat tentnag identitas program Bincang Santai INewa TV Batam.

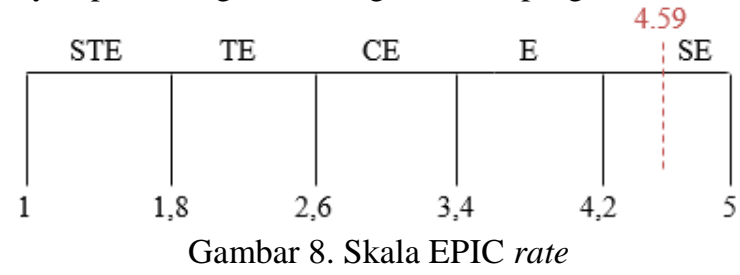

\section{KESIMPULAN}

1) Proses perancangan dan pembuatan video opening bumper program Bincang Santai iNews Batam dalam bentuk motion graphic berhasil dilakukan dengan menggunakan metode Sherwood-Rout. Video opening bumper yang dihasilkan memiliki durasi 18 detik dalam format .mpg. Video opening bumper berisikan cuplikan singkat tentang program Bincang Santai iNews Batam dengan didukung berbagai elemen motion graphic.

2) Hasil analisis uji kelayakan produk sebagai opening bumper program Bincang Santai iNews Batam berdasarkan indikator elemen opening bumper yang meliputi tipografi, warna, efek visual, objek visual, dan music backsound mencapai nilai 4.15 yang dikategorikan Layak, artinya opening bumper yang telah dibuat layak menjadi opening bumper Program Bincang Santai iNews Batam.

3) Hasil analisis efektifitas produk sebagai opening bumper pada program Bincang Santai INews TV Batam mencapai nilai rata-rata dimensi EPIC model sebesar 4,59, sehingga produk ini sangat efektif sebagai penyampaian singkat tentang identitas program Bincang Santai INews TV Batam.

\section{DAFTAR PUSTAKA}

[1] Morissan, MA, ”Manajemen Media Penyiaran. Jakarta: Prenada Media Group,” 2008.

[2] Algiffari M., "Perancangan Motion Graphic (Bumper In) dan Video Dokumenter Permainan Tradisional Jawa Barat (Analisis Deskriptif Permainan Tradisional Pada Sanggar Seni Tikukur Majalengka)”, Jurnal Sketsa, Vol.II No.1, 2015. Tersedia di: https://ejournal.bsi.ac.id/ejurnal/index.php/sketsa/article/view/431

[3] Priyatmanto B.A., "Perancangan Media Motion Graphic OBB Program TV Holiday Night Di Kompas TV Surabaya," Universitas Dinamika, 2013. Tersedia di: http://repository.dinamika.ac.id/id/eprint/145/ 
[4] Tangguh Wisnu Afandi, "Perancangan Motion Graphic Biografi Grup dan Musisi Pelopor Musik Rock di Indonesia Edisi Majalah Rolling Stone Indonesia,” . Skripsi thesis, Institut Seni Indonesia Yogyakarta.2015.

[5] Evaliata Br. Sembiring dan Peter Lim, "Edukasi Adaptasi Kebiasaan Baru Di Lingkungan Kampus (Studi Kasus: Motion Graphic Penggunaan Lift)", Journal of Digital Education, Communication, and Arts, Vol. 3, No. 2, September 2020. Tersedia di: https://jurnal.polibatam.ac.id/index.php/DECA/article/view/2473/1209

[6] Yesty Desca Refita Putri, Pembuatan Motion Graphics sebagai Media Sosialisasi dan Promosi untuk Aplikasi Mobile Trading Online Mandiri Sekuritas, KOPERTIP: Jurnal Ilmiah Manajemen Informatika dan Komputer, Vol.01 N0.02, 2017. Tersedia di: https://www.neliti.com/publications/227018/pembuatan-motion-graphicssebagai-media-sosialisasi-promosi-untuk-aplikasi-mobil

[7] Yunita A., Condra A., dan Sandi P., Analisis dan Implementasi Motion Grafis Iklan Layanan Masyarakat (ILM) dengan Metode Semiotika Pierce, Jurnal Ilmu Komunikasi Ekspresi \& Persepsi, Vol.1 No.1, 2018. Tersedia di: https://ejournal.upnvj.ac.id/index.php/JEP/article/view/444/360

[8] Iwan Binanto, "Kajian Metode-metode Pengembangan Perangkat Lunak Multimedia", Jurnal Penelitian Vol.17 No.1 2013. Tersedia di: https://e-journal.usd.ac.id/index.php/JP/article/view/784

[9] Balqis Media Utama, "Video Opening Acara," 2017. Tersedia di: http://balqismu.com/video-opening-acara/

[10] Naufan Noordyanto, "Studi Tipografi Kawasan di Yogyakarta, Jurnal Disain Komunikasi Visual (Dekave), Vol.9 No.1, 2016, Tersedia di: http://journal.isi.ac.id/index.php/dkv/article/view/1659

[11] https://id.m.wikipedia.org/wiki/Tipografi, diakses tanggal 4 Maret 2021.

[12] https://edu.gcfglobal.org/en/beginning-graphic-design/color/1/, diakses tanggal 4 Maret 2021.

[13] Keng-Lin Soh, K.Jayaraman, Li-Peng C., Shayan K., "The Impact of Background Music on The Duration of Consumer Stay at Stores: An Empirical Study in Malaysia”, International Journal Of Business and Society, Vol.16 No.2, 2015

[14] http://youtube.com/najwa-shihab, diakses tanggal 4 Maret 2021.

[15] Ria Diajeng Anita dan Fitri Marisa, "Rancangan Video media Promosi Berbasis Motion Graphic 2D Untuk Meningkatkan Jumlah Mahasiswa Universitas Widyagama Malang,” 2017.

[16] Evaliata Br Sembiring dan Ega Florentina, MULTIMEDIA-Media untuk Mendokumentasikan Aplikasi Komputer, PolibatamPres, Batam, 2020. 